\title{
Arabic Text Classification Algorithm using TFIDF and Chi Square Measurements
}

\author{
Aymen Abu-Errub \\ Assistant Professor \\ Department of Network and \\ Information Security, Faculty of IT, \\ Al-Ahliyya Amman University, \\ Amman, Jordan
}

\begin{abstract}
Text categorization is the process of classifying documents into a predefined set of categories based on its contents of keywords. Text classification is an extended type of text categorization where the text is further categorized into subcategories. Many algorithms have been proposed and implemented to solve the problem of English text categorization and classification. However, few studies have been carried out for categorizing and classifying Arabic text. Compared to English, the Arabic text classification is considered as a very challenging due to the Arabic language complex linguistic structure and its highly derivational nature where morphology plays a very important role. This paper proposes a new method for Arabic text classification in which a document is compared with pre-defined documents categories based on its contents using the TF.IDF method (Term Frequency times Inverse Document Frequency) measure, then the document is classified into the appropriate sub-category using Chi Square measure..
\end{abstract}

\section{General Terms}

Information Retrieval.

\section{Keywords}

Text Categorization, Text Classification, Term Frequency, Inverse Document Frequency, Chi Square.

\section{INTRODUCTION}

According to the Internet World Stats (http://www.internetworldstats.com/stats7.htm), Arabic is the fifth most used language in the world, spoken by almost 340 million people in 27 states. The Arabic language is one of the oldest known spoken languages as well as one of the official languages of the United Nations. It belongs to the Semitic language family originated in the Arabian Peninsula in preIslamic times, and spread rapidly across the Middle East [4]. The Arabic language is very interesting in terms of its history, the strategic value of its people and the region they live in, and its cultural legacy. Historically, for more than fifteen centuries, classical Arabic remained unaffected, comprehensible and functional. At the Strategic level, Arabic is the native language of almost 340 million speakers occupying a main region with vast oil reserves important to the world economy. Culturally, the Arabic language is closely associated with Islam in which 1.4 billion Muslims perform their prayers five times daily [6].

Text categorization (TC) refers to the process of classifying free text, to predefined categories, assigning to it one or more category label. TC has been widely employed in many areas such as email classification, information retrieval and junk email filtering. There are two main approaches for text categorization: the knowledge engineering approach and the supervised learning approach. In the knowledge engineering approach, the classification rules are manually created by domain experts. While in the supervised learning approach, machine learning techniques automatically build the classifiers based on a set of labeled documents. Technically, for each input document $d$ and category $c$, text classification involves two steps: (1) estimating the extent to which $d$ shares semantics with $c$, and (2) based on the estimation, deciding whether $d$ may be classified into $c$. In the first step, classifiers need to assess the similarity score of $d$ with respect to $c$. In the second step, classifiers need to associate a threshold to $c$. If the similarity score of $d$ with respect to $c$ is higher than or equal to the threshold of $c, d$ is classified into $c$, otherwise it is not classified into $c[8,10,16]$.

Nowadays, due to the increasing amount of valuable textual information, it becomes a problem or a challenge for humans to manually manipulate this huge amount of information and identify the most relevant information or knowledge. Therefore, Automatic text categorization plays an important role in helping information users overcome such a challenge by reducing the time needed to classify thousands of daily arrived documents, without the need for experts. Thus, Automatic TC can significantly reduce the cost and effort of manual categorization [3]. For example, it has been reported in the Internet World Stats (http://www.internetworldstats.com/stats7.htm) that the number of Arabic speaking Internet users has grown 2,501.2 $\%$ in the last eleven years (2000-2011), which is the highest growth rate among other languages. Consequently, with the increasing amount of Arabic textual information, there is a need to propose, develop and employ Arabic TC algorithms in order to store and divide textual information into categories. Thus, assisting the Arabic users to navigate to the information they would like to obtain

Compared to other languages, there is still a limited research which has been carried out for the Arabic text categorization and classification due to the complex and rich nature of the Arabic language and its highly derivational nature where morphology plays a very important role [6, 14]. Additionally, most of such research includes supervised machine learning techniques in which most of these techniques have complex mathematical models and do not usually lead to accurate results for Arabic TC [14]. Accordingly, much more research is needed to further develop and refine the area of Arabic TC. In this study, the researcher will apply both a vector classification method and Chi square measurement for Arabic 
text classification in which similar documents are grouped into categories and sub-categories based on their contents. The rest of this paper is organized as follows: In Section 2, a brief overview of the related studies in which a number of research papers that deal with the area of Arabic TC and Arabic root extraction are reviewed. Section 3 shows the proposed algorithm. Section 4 presents the experimental results. Finally, conclusions and directions for future study are provided in Section 5.

\section{RELATED WORKS}

Many researches have been carried out on text categorization in English. However, researches on text categorization for Arabic language are quite limited [6, 14]. Among the successful approaches for Arabic Text categorization, a number of recent studies have been proposed $[1,2,5,7,9,11$ $15,17]$.

In the paper of Syiam et al. [15], an intelligent Arabic text categorization model is presented. For Arabic text categorization, the proposed model uses: 1) statistical n-gram stemmer for document pre-processing, 2) a hybrid approach of Document Frequency Thresholding and Information Gain for feature selection, 3) normalized TF-IDF for term weighting, and 4) Rocchio classifier for classification. Experimental results demonstrate the effectiveness of the proposed model and gives generalization accuracy of about $98 \%$.

Mesleh [11] implemented a text classification system for Arabic language articles. The implemented system uses 1) CHI statistics as a feature extraction method in the preprocessing step of the text classification system design procedure, and 2) Support Vector Machines (SVMs) classification model for TC tasks for Arabic language articles. The author collected corpus from online Arabic newspaper archives, including Al-Jazeera, Al-Nahar, Al-hayat, AlAhram, and Al-Dostor in addition to a few other specialized websites. The collected corpus contains 1445 documents which were falling into 9 classification categories. Experimental results show a high classification effectiveness for Arabic data set in term of $F$-measure $(F=88.11)$ compared to other classification methods.

Al-Harbi et al. [2] presented the results of experiments of document classification performed on seven different Arabic corpora using statistical methodology. A tool was implemented for feature extraction and selection and the performance of two popular classification algorithms (SVM and C5.0) in classifying the seven Arabic corpora has been evaluated. Generally, C5.0 classifier shows better classification accuracy than SVM.

Harrag et al. [9] enhanced Arabic text classification by feature selection based on hybrid approach of Document Frequency Thresholding using an embedded information gain criterion of the decision tree algorithm. Experiments are conducted over two self collected data corpus. The first corpus is a set of Arabic texts from the Arabian scientific encyclopedia "Do You Know". It contains 373 documents fitting in 8 categories. The second corpus is a set of prophetic traditions collected from Prophetic encyclopedia "The Nine Book". It contains 435 documents fitting in 14 categories. The study demonstrated the effectiveness of proposed classifier and gives classification accuracy of $0.93 \%$ for the scientific corpus and $0.91 \%$ for the literary corpus.

Noaman et al. [13] introduced the use of rooting algorithm with Naïve Bayes classifier to resolve the problem of Arabic document categorization. To validate the proposed classification algorithm, the authors created a corpus of 300 documents belong to 10 categories which were selected based on the most popular categories from many newspaper articles collected from different online newspaper websites. The experimental study shows the success of the proposed classifier in terms of error rate, accuracy, and micro-average recall measures, and achieves $62.23 \%$ of classification accuracy.

Alsaleem [5] discussed the problem of automatically classifying Arabic text documents and used Naïve Bayesian method (NB) and Support Vector Machine algorithm (SVM) on different Arabic data sets to handle the Arabic text classification problem. The Experimental results against different SNP Arabic text categorization data sets confirm that SVM algorithm outperforms the NB with regards to F1, Recall and Precision measures.

Molijy et al. [12] proposed and implemented an automatic Arabic document indexing method to automatically create and Index Arabic books. The proposed method depends mainly on text summarization and abstraction processes to gather main topics and statements in the book. It is start by the preprocessing step which removes irrelevant text (e.g. punctuation marks, diacritics, non-letters, etc.). Then it computes the frequency of every term in the document and reorders them in a descending order. After that, a ranking algorithm is used to remove all terms with highest and lowest frequency. Finally, the system matches between the term and the page number where the term occurs in the document and automatically adds the index to the end of the document. Experimental results in terms of accuracy and performance show that the proposed method can effectively replace the human time consuming effort for indexing a large number of documents or books.

Al-Diabat [1] investigated the problem of Arabic text categorization using different rule-based classification data mining algorithms. These algorithms, which have been contrasted on the problem of Arabic text classification, are: One Rule, rule induction (RIPPER), decision trees (C4.5), and hybrid (PART). Inclusive experiments have been carried out against known Arabic text collection called SPA with respect to different evaluation measures such as error rate, number of rules, etc, to determine the best performing algorithm in regards to the Arabic text classification problem. The results show that the most applicable algorithm is the hybrid approach of PART in which it achieved better performance that the rest of the algorithms.

Zaki et al. [17] proposed a hybrid approach based on n-grams and the OKAPI model for the indexing and classification of an Arabic corpus. The hybrid approach takes into account the concept of the semantic vicinity of terms and the use of a radial basis modelling. The use of semantic terminological resources such as semantic graphs and semantic dictionaries significantly improves the process of indexing and classification. The hybridization of NGRAMs-OKAPI statistical measures and a kernel function is used to calculate the similarity between terms in order to identify the relevant concepts which represent best a document.

Goweder et al. [7] developed a Centroid-based technique for Arabic text classification. The proposed algorithm is evaluated using a corpus containing a set of 1400 Arabic text documents covering seven distinct categories. The experimental results show that the adapted Centroid-based algorithm is applicable to classify Arabic documents. The 
performance criteria of the implemented Arabic classifier achieved approximately figures of $90.7 \%, 87.1 \%, 88.9 \%$, $94.8 \%$, and $5.2 \%$ of Micro-averaging recall, precision, Fmeasure, accuracy, and error rates respectively.

Sharef et al. [14] introduced a new Frequency Ratio Accumulation Method (FRAM) approach for the Arabic TC. The proposed approach has a simple mathematical model and it combines the categorization task with the feature selection task. The combination leads to reduce the computational operations of Arabic TC system unlike the other methods which deal with feature selection and classification as a major process of automated TC. The performance of FRAM classifier is compared with three classifiers based on the Bayesian theorem, namely the Simple NB, Multi-variant Bernoulli Naïve Bayes (MNB) and Multinomial Naïve Bayes models (MBNB). Experimental results show that the FRAM has outperformed the simple NB, MNB and MBNB which are the major methods of supervised Machine Learning. The FRAM achieved $95.1 \%$ macro-F1 value by using unigram word-level representation method.

Yousef et al. [14] introduced a new technique to extract Arabic word's roots using N-gram method. The proposed algorithm consists of several steps; it starts by normalizing the word, then dividing it into bi-grams and calculate the similarity between the original words and candidate roots select from the roots list. The researchers tested their algorithm on a 141 roots corpus. The results show that the proposed algorithm is capable of extracts the most possible roots of nearly $80 \%$ of the strong roots.

\section{PROPOSED ALGORITHM}

The proposed algorithm is consists of two stages; categorization stage and classification stage. Following is the description of each stage.

Categorization Stage: in this stage the tested document is categorized into one of 10 categories. The categorization process is done by comparing the key words of the test document with the key words of each category, by using TF.IDF measurement, and then the most related category is chosen. Steps 1 to 6 of the proposed algorithm represent this stage.

Classification Stage: in this stage a further comparing process is done, this time between the tested document and the documents in sub-categories of the chosen main category. The comparing process is done by using Chi square measurement to find the index words of each subcategory of the main category. This stage is represented by steps 7 and 8 of the proposed algorithm. Following are the steps of the proposed algorithm:

Step1 (Categorization Stage): Delete stop words from the tested document. Table (1) shows some Arabic stop words:
Table 1. Arabic Stop Words

\begin{tabular}{|c|c|c|c|c|c|}
\hline نمز & Lأ & أتز & نتخ & أنسا & تأن \\
\hline : & as & 2 & las & هى & $\mu$ \\
\hline إزأكي & أ & عالن & هذان & is & lis \\
\hline اليانا & اليالى & إيهن & الياكئ & Lبا & إيك \\
\hline النى & 24 & لبالم & ليالشا & 64 & اليال \\
\hline تلز الى & اللإتى & الذينين & 'لتان & الندأن & ت" \\
\hline$y$ & لين & له & بلا & 4 & 4 \\
\hline على & ה & بلى & حَّى & i & لف \\
\hline sis & أي & لُم & j & ن & e \\
\hline ثنَّى & كر & أبن & جل جل & نع & كي \\
\hline اليان & i & i & is & يبات & Lilat \\
\hline رب & حبنا & حين & للان & أتى & لـ \\
\hline بين & ريبنا & سبا & حبنا & حبب & رببا \\
\hline Lit & it & كبها & كين & 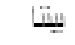 & بينا \\
\hline بئ山ا & حبث & تلكي & Let & Hi & St \\
\hline فزو & نمر & 46 & L & مرزما & لدون \\
\hline قُلَ & خالت & ورداء & أكلية & نصت & أعلى \\
\hline اندلأيق & الجزلز & th & تا & جزار & בَلم \\
\hline النا & i) & الأن & ذلال & بحلفا & بحذ \\
\hline 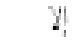 & حائا & ع & ذلا & بلا & W \\
\hline S & بلد & عزض & عiالبل & ألر & I \\
\hline كليز & 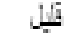 & بكض & أغلب & المطلم & جزء \\
\hline غزوب & شروز & طلرع & أخر & أرل & البالز \\
\hline صدلر & كن & بكرن & كان & أَصير & طريل \\
\hline نت & لبّ & (t) & نلت & أسيى & تصبح \\
\hline كأن & ب & إن & لدام & لبرع & زال \\
\hline الد & واهذ & صنر & باكن & لكن & w \\
\hline خاس & أربي & لذأث & لتنال & أثلان & الحنى \\
\hline ella & ثشر & لني & ثئان & بلب & 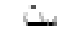 \\
\hline نبلة & بلابة & يليلز & بلبزن & اليزئن & 'تل \\
\hline نظيز & عثبا & بكرi & عساء & صبات & برئi \\
\hline لئرام & أفس & البزانة & علم & 4 & ساكة \\
\hline نصن & نبار & بلب & لبال. & 4 & غن \\
\hline هi & $\mathrm{jo}^{\circ}$ & ســس & خاس & 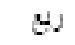 & 4 \\
\hline
\end{tabular}


Step2: Normalize the rest of the tested document: this step consists of several processes such as:

- Removing punctuation.

- Deleting numbers, spaces and single letters.

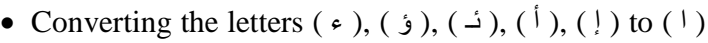
and $(\ddot{0})$ to $(0)$.

Step3: Apply stemming process to the tested document's words to delete affixes (suffixes and prefixes) letters and extract the root of each word in the document.

Step4: Find the index terms of both the testing documents and the tested document by calculating the weight of each word using TFIDF - Term Frequency $\left(\mathrm{tf}_{\mathrm{ij}}\right.$ ) and the Inverse Document Frequency $\left(\log \left(\mathrm{N} / \mathrm{df}_{\mathrm{j}}\right)\right)$ - measurement as shown in the following equation:

$$
\mathrm{Wij}=\mathrm{tf}_{\mathrm{ij}} * \log \left(\mathrm{N} / \mathrm{df}_{\mathrm{j}}\right)
$$

Step5: Choose the top three words that have the largest weight in the tested document (index words).

Step6: Compare the index words of the tested document with the index words of each testing category to find the most suitable main category.

Step7 (Classification Stage): Calculate the weight of each word in the main category chosen in step 6 using Chi square measurement to select the index words of each sub-category. This step is done by applying the following equation:

$$
\chi^{2}\left(\mathrm{w}, \mathrm{s}_{\mathrm{i}}\right)=\frac{\mathrm{N} \times(\mathrm{AD}-\mathrm{CB})^{2}}{(\mathrm{~A}+\mathrm{C}) \times(\mathrm{B}+\mathrm{D}) \times(\mathrm{A}+\mathrm{B}) \times(\mathrm{C}+\mathrm{D})}
$$

Where:

w: The word to be weighted.

$\mathrm{s}_{\mathrm{i}}$ : The $\mathrm{i}^{\text {th }}$ sub-category.

$\mathrm{N}$ : Total number of documents in the main category.

A: Number of documents in sub-category $s_{i}$ that containing word $\mathrm{w}$.

B: Number of documents in sub-category $s_{i}$ that do not containing word $\mathrm{w}$.

C: Number of documents not in sub-category $s_{i}$ but containing word $\mathrm{w}$.

D: Number of documents neither in sub-category $s_{i}$ nor containing word $\mathrm{w}$

Step8: Calculate the similarity between the index words of the tested document and the index words of each subcategory of the chosen main category.

Step9: Return the name of main and sub category the has highest matching percentage

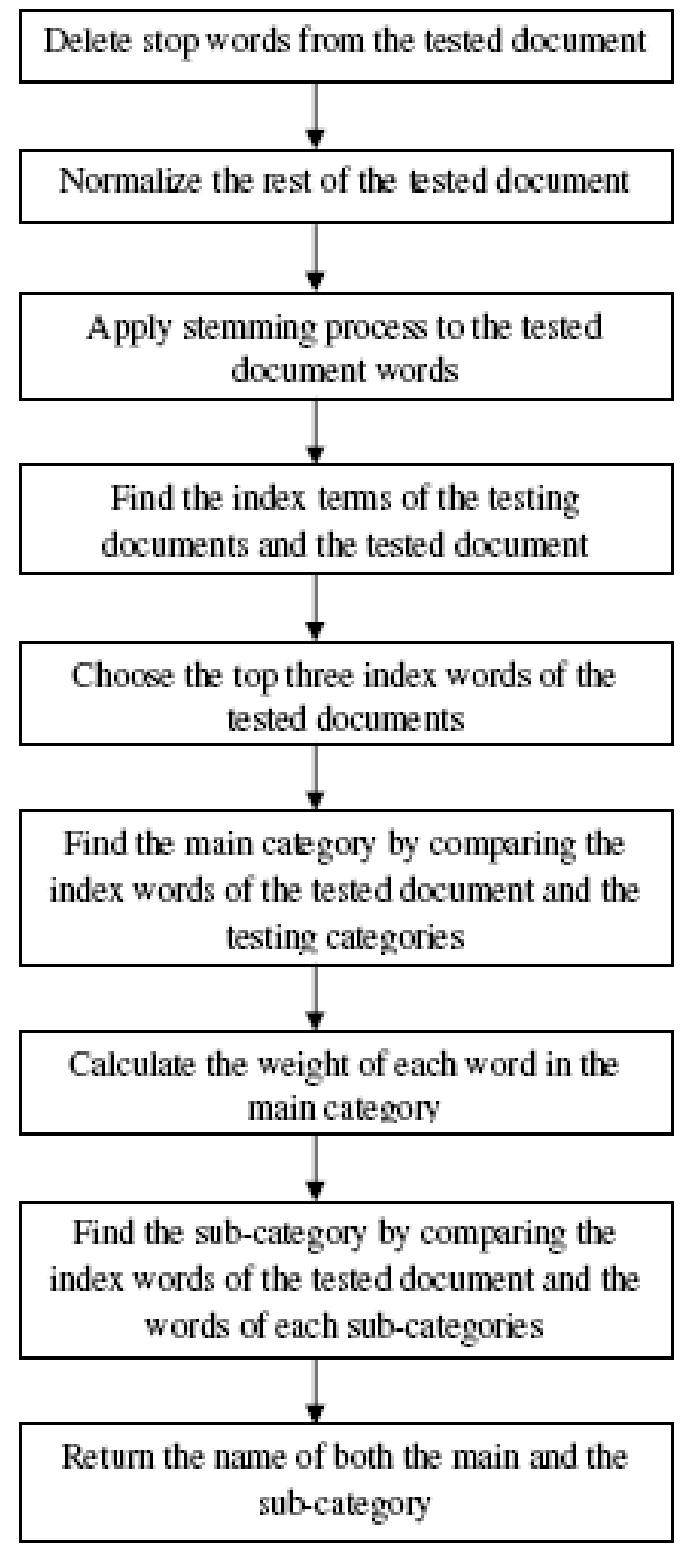

Figure 1: Arabic Text Classification Algorithm

\section{EXPERIMENTAL RESULT}

To examine the proposed algorithm the researcher chose a training set of Arabic articles covering different topics. These documents are categorized into ten main categories and 50 subcategories containing 1090 documents with variant size and content. These documents are used as learning document set to apply the proposed algorithm. Table 2 shows both the main and sub-categories of the training set and the number of documents in each category: 
Table2: Main and Sub Categories of the Training Documenting Set.

\begin{tabular}{|c|c|c|c|c|c|}
\hline $\begin{array}{c}\text { Main } \\
\text { Category }\end{array}$ & $\begin{array}{c}\text { Sub } \\
\text { Categories }\end{array}$ & $\begin{array}{c}\# \\
\text { Doc. }\end{array}$ & $\begin{array}{c}\text { Main } \\
\text { Category }\end{array}$ & Sub Categories & $\begin{array}{c}\# \\
\text { Dac. }\end{array}$ \\
\hline \multirow{5}{*}{ Agriculture } & $\begin{array}{l}\text { Aquatic } \\
\text { Species }\end{array}$ & 20 & \multirow{5}{*}{ Environment } & Ecology & 20 \\
\hline & Animal Feed & 28 & & Physics & 28 \\
\hline & Spices & 23 & & Chemistry & 23 \\
\hline & $\begin{array}{l}\text { Poultry } \\
\text { Farming }\end{array}$ & 20 & & Soil Science & 19 \\
\hline & Forestry & 20 & & Geography & 26 \\
\hline \multirow{5}{*}{ Astronomy } & Moons & 24 & \multirow{5}{*}{ Biology } & Cell Theory & 21 \\
\hline & Planets & 26 & & Evolution & 18 \\
\hline & Stars & 22 & & Genetics & 24 \\
\hline & Nebula & 16 & & Homeostasis & 16 \\
\hline & Galaxies & 18 & & Systematic & 19 \\
\hline \multirow{5}{*}{ Business } & $\begin{array}{l}\text { Ekctronic } \\
\text { Commeroe }\end{array}$ & 27 & \multirow{5}{*}{ Chemistry } & Atom & 21 \\
\hline & $\begin{array}{l}\text { Industrial } \\
\text { Automation } \\
\text { Business }\end{array}$ & 23 & & Element & 23 \\
\hline & $\begin{array}{l}\text { Social } \\
\text { Business }\end{array}$ & 24 & & Compound & 18 \\
\hline & Markting & 19 & & Ions \& Salts & 27 \\
\hline & Healthcare & 17 & & Acidity & 22 \\
\hline \multirow{5}{*}{ Computer } & Network & 23 & \multirow{5}{*}{ Sport } & Swimming & 21 \\
\hline & Hardware & 25 & & Water Polo & 18 \\
\hline & Software & 20 & & Tennis & 23 \\
\hline & CIS & 21 & & Bascball & 20 \\
\hline & Multimedia & 19 & & Football & 28 \\
\hline \multirow{5}{*}{ Economics } & Markets & 25 & \multirow{5}{*}{ Tounism } & $\begin{array}{l}\text { Healthy } \\
\text { Tourism }\end{array}$ & 21 \\
\hline & $\begin{array}{l}\text { Production } \\
\text { \& Efficiency }\end{array}$ & 24 & & $\begin{array}{l}\text { Cultural } \\
\text { Tourism }\end{array}$ & 25 \\
\hline & $\begin{array}{l}\text { Supply \& } \\
\text { Demand }\end{array}$ & 21 & & Nature Tounism & 19 \\
\hline & $\begin{array}{l}\text { Industrial } \\
\text { Organization }\end{array}$ & 19 & & $\begin{array}{l}\text { Religion } \\
\text { Tourism }\end{array}$ & 20 \\
\hline & $\begin{array}{l}\text { International } \\
\text { Tradk }\end{array}$ & 23 & & Accommodation & 23 \\
\hline
\end{tabular}

The Proposed algorithm was implemented at a set of tested documents consist of 1100 document. The results of test show that the proposed algorithm is capable of categorize the tested documents to a main category and then classify these tested documents into a suitable sub-category. Table (3) shows the results of categorizing selected tested documents to main category. Table (4) shows the results of classifying tested documents into sub-category of the main category
Table 3: Sample of Proposed Algorithm Percentage Results for Categorization Stage

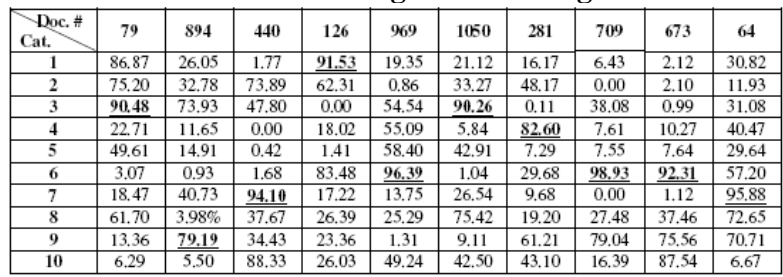

Table 4: Sample of Proposed Algorithm Percentage Results for Classification Stage

\begin{tabular}{|l|c|c|c|}
\hline Doc. \# & $\mathbf{9 6 9}$ & $\mathbf{7 0 9}$ & $\mathbf{6 7 3}$ \\
\hline Ecology & 20.33 & 22.43 & 17.06 \\
\hline Physics & 0.90 & 35.00 & 48.80 \\
\hline Chemistry & 59.55 & $\mathbf{9 8 . 9 3}$ & 0.12 \\
\hline Soil Science & $\mathbf{9 6 . 3 9}$ & 6.53 & $\underline{\mathbf{9 2 . 3 1}}$ \\
\hline Geography & 66.09 & 45.42 & 7.33 \\
\hline
\end{tabular}

\section{CONCLUSION}

This research introduced a dual-stages Arabic text classification algorithm using TFIDF measurement for categorization stage and Chi square measurement for classification stage. The researcher examines the proposed algorithm using 1090 testing (training) documents categorized into ten main categories and 50 sub categories. The tested documents set was consists of 1100 different documents. The experimental results show that the proposed algorithm is capable of classifying the tested documents to its appropriate sub category.

\section{REFERENCES}

[1] A. Alatabbi, and C. S. Iliopoulos, "Morphological analysis and generation for Arabic language." pp. 1-9.

[2] A. Farghaly, and K. Shaalan, "Arabic Natural Language Processing: Challenges and Solutions," ACM Transactions on Asian Language Information Processing, vol. 8, no. 4, pp. 1-22, 2009.

[3] R. Guzmán-Cabrera, M. Montes-y-Gómez, P. Rosso et al., "Using the Web as corpus for self-training text categorization," Information Retrieval, vol. 12, no. 3, pp. 400-415, 2009.

[4] A. H. Wahbeh, and M. Al-Kabi, "Comparative Assessment of the Performance of Three WEKA Text Classifiers Applied to Arabic Text," Abhath AlYarmouk: Basic Sci. \& Eng., vol. 21, no. 1, pp. 15-28, 2012.

[5] R. L. Liu, "Context recognition for hierarchical text classification," Journal of the American society for information science and technology, vol. 60 , no. 4, pp. 803-813, 2009.

[6] R. Al-Shalabi, G. Kanaan, and M. Gharaibeh, "Arabic text categorization using kNN algorithm." pp. 1-9.

[7] B. Sharef, N. Omar, and Z. Sharef, "An Automated Arabic Text Categorization Based on the Frequency Ratio Accumulation," International Arab Journal of Information Technology (IAJIT), vol. 11, no. 2, pp. 213 221, 2014. 
[8] A. Goweder, M. Elboashi, and A. Elbekai, "CentroidBased Arabic Classifier." pp. 1-8.

[9] A. A. Molijy, I. Hmeidi, and I. Alsmadi, "Indexing of Arabic documents automatically based on lexical analysis," International Journal on Natural Language Computing, vol. 1, no. 1, pp. 1-8, 2012.

[10] M. Al-diabat, "Arabic Text Categorization Using Classification Rule Mining," Applied Mathematical Sciences, vol. 6, no. 81, pp. 4033-4046, 2012.

[11] S. Alsaleem, "Automated Arabic Text Categorization Using SVM and NB," Int. Arab J. e-Technol., vol. 2, no. 2, pp. 124-128, 2011.

[12] T. Zaki, D. Mammass, A. Ennaji et al., "Arabic Documents Classification by a Radial Basis Hybridization." pp. 37-44.
[13] M. M. Syiam, Z. T. Fayed, and M. Habib, "An intelligent system for Arabic text categorization," International Journal of Intelligent Computing and Information Sciences, vol. 6, no. 1, pp. 1-19, 2006.

[14] S. Al-Harbi, A. Almuhareb, A. Al-Thubaity et al., "Automatic Arabic text classification." pp. 77-83.

[15] A. M. d. A. Mesleh, "Chi Square Feature Extraction Based Svms Arabic Language Text Categorization System," Journal of Computer Science, vol. 3, no. 6, 2007.

[16] F. Harrag, E. El-Qawasmeh, and P. Pichappan, "Improving arabic text categorization using decision trees." pp. 110-115.

[17] H. M. Noaman, S. Elmougy, A. Ghoneim et al., "Naive Bayes Classifier based Arabic document categorization." pp. 1-5. 